\title{
Erratum to: Heinz Heinemann's Legacy at ExxonMobil: An Illustrious Career in Industrial Catalysis
}

\author{
Thomas F. Degnan Jr. • Nai Y. Chen
}

Published online: 22 October 2009

(C) Springer Science+Business Media, LLC 2009

\section{Erratum to: Catal Lett}

DOI 10.1007/s10562-009-0153-2

This article inadvertently lists Editor-in-Chief Gabor Somorjai as an author of the paper. The correct author list is Thomas F. Degnan Jr. and Nai Y. Chen. We regret the error.

The online version of the original article can be found under doi:10.1007/s10562-009-0153-2.

T. F. Degnan Jr. ( $\square)$

ExxonMobil Research and Engineering, 1545 Route 22 East,

Clinton Twp, Annandale, NJ 08801, USA

e-mail: thomas.f.degnan@exxonmobil.com

N. Y. Chen

Mobil Technology Company, 4 Forrest Central Drive,

Titusville, NJ 08560, USA

e-mail: naiychen@earthlink.net 